\title{
(2) OPEN ACCESS \\ See you in court: obstacles to enforcing the ban on electronic cigarette flavours and marketing in Finland
}

\author{
Eeva Olila (1) 1,2
}

${ }^{1}$ Health Department, Cancer Society of Finland, Helsinki, Finland

${ }^{2}$ Faculty of Social Sciences, Tampereen Yliopisto, Tampere, Finland

\section{Correspondence to} Dr Eeva Ollila, Health Department, Cancer Society of Finland, Helsinki 00130, Finland; eeva.ollila@cancer.fi

Received 1 July 2019

Revised 13 September 2019 Accepted 16 September 2019 Published Online First 21 October 2019

\section{ABSTRACT}

The aim of Finnish tobacco policy is to end the use of tobacco and other nicotine-containing products by 2030. Towards that end, the regulation of electronic cigarettes (e-cigarettes) in Finland is stricter than that in other European Union (EU) countries, including a ban on characterising flavours in e-cigarette liquids as well as on marketing e-cigarettes. This article describes the e-cigarette market, its regulation and the challenges faced in enforcing regulations in Finland. The materials used for this study include data from tobacco control authorities on retail licences, product notifications, and guidance and decisions concerning enforcing regulations, as well as public documents from the courts concerning e-cigarette-linked appeals on selling flavours and marketing e-cigarettes. Legislation and documents produced during legislative processes are also used. Access to e-cigarettes is limited, as only $5 \%$ of retailers for tobacco or nicotine products have a licence for retailing nicotine liquids. Liquids containing flavours but without nicotine are commonly sold by specialised e-cigarette shops and websites as foodstuffs. Effective regulation is hampered by the enormous number and variety of e-cigarette products notified for potential market access, limited resources for tobacco control to expand in scope and reluctance of the e-cigarette business to comply with the stricter regulations in Finland, resulting in court cases filed by e-cigarette businesses. Mounting evidence suggests that regulating flavours in e-cigarettes to protect youth is wise although not easy. Many counties are currently considering further regulations on e-cigarettes and so should the EU.

\section{E-CIGARETTES AND THEIR REGULATION IN FINLAND}

In 2010, Finland became the first country in the world to make ending the use of tobacco the goal of its Tobacco Act. In 2016, the reform of the act (Tobacco Act 549/2016, or TA2016), ${ }^{1}$ which implemented the Tobacco Product Directive (TPD) of the European Union, ${ }^{2}$ broadened this objective to include other nicotine-containing products that are addictive and toxic.

Electronic cigarettes (e-cigarettes) came on the Finnish market in 2011 and $2012,{ }^{3}$ but the sale of e-cigarette devices and nicotine-free liquids was not regulated. E-cigarette devices were readily available and displayed, among them candy-coloured e-shishas marketed alongside confectionary. Nicotine containing e-liquids (nicotine liquids) were regulated under the Medicines Act, though none were available on the domestic market. Nicotine liquids could be legally purchased online from abroad. ${ }^{4}$
With the objective of making Finland nicotinefree, the national implementation of the TPD by the TA2016 enforced tighter control on e-cigarettes than most other countries, ${ }^{5}$ the most marked difference being the ban on characterising flavours or aromas in e-cigarette liquids (flavours), defined in the TA2016 as 'smell or taste other than one of tobacco' in both nicotine-containing and nicotinefree liquids intended for vaporisation. ${ }^{1}$ The specific aim of this provision was to prevent children and youngsters from taking up vaping, while those adults already addicted to nicotine and wanting to revert to e-cigarettes could do so as nicotinecontaining liquids became available. The potential health risk of the flavours was another justification for the ban. ${ }^{6}$

Other additional national provisions regarding e-cigarettes include age limits for buyers, and the prohibition of marketing, displaying and distance selling, including internet purchases, import restrictions and use in non-smoking areas. The display ban does not, however, apply to sales outlets that sell almost exclusively tobacco and nicotine products, provided that visibility from outside to the retail premises was blocked. To curb the use of tobacco and nicotine products, retail licence is required, a sizeable supervision fee (up to $€ 500 /$ cashier) applied separately for tobacco products and for nicotine liquids, as well as tax also on nicotine liquids. ${ }^{1}$

With the TA2016, e-cigarette devices and nicotine-free liquids disappeared from grocery stores and kiosks, and the availability of e-cigarettes devices and liquids was initially almost exclusively in newly established specialised e-cigarette shops. Despite the ban on selling flavours, in 2017, the specialised e-cigarette outlets were found to sell flavours, although not in ready-made mixes with nicotine liquids. ${ }^{4}$

Currently, use of e-cigarettes is lower in Finland than in most European Union (EU) countries, but has increased also in Finland between 2014 and 2017. ${ }^{7}$ Increasing use of e-cigarettes among youth raises concerns in many countries. ${ }^{89}$ In Finland, the prevalence of daily e-cigarette use among eighth and ninth graders in 2019 was 3.5\% for men and 1.1\% for women ${ }^{10}$ (figure 1). Smoking among youth is decreasing, but the use of snus has increased among young men, and concurrent smoking and snus is common. ${ }^{11-13}$

The $\mathrm{TPD}^{2}$ had left regulating flavours to the member states, while stating in its preambular 47 that allowing flavours could be useful and any prohibition needed to be justified and notified, which Finland did. ${ }^{14}$ As a result of the notification process, products with tobacco smell or taste were allowed. 


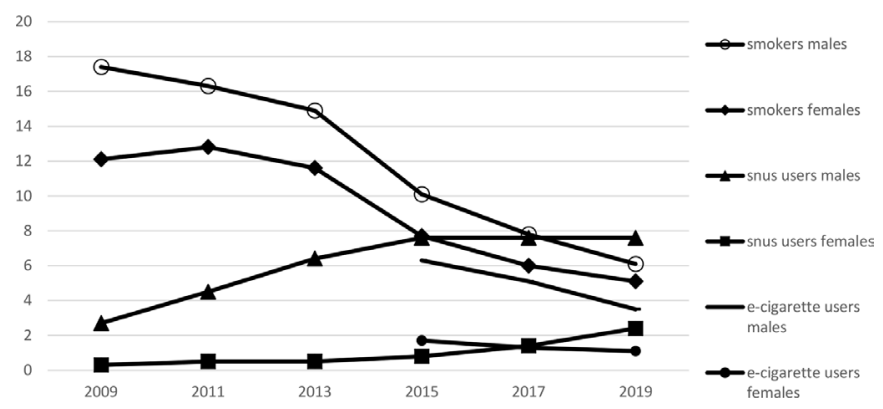

Figure 1 Daily smokers and snus and e-cigarette users among youth in the eighth and ninth grade in Finland in 2009-2019. ${ }^{10}$

TA2016 (sections 22 and 26), corresponding Article 20, paragraph 2 of the TPD, ${ }^{2}$ charges the manufacturers and importers of e-cigarettes and refill containers with submitting a notification to the competent authorities of the member states of products that they intend to place on the market. These notifications must include information on the ingredients and toxicological data regarding the product's ingredients and emissions, including when heated and inhaled, as well as a declaration bearing full responsibility for the quality and safety of the product. Flavours without nicotine are not included in these provisions.

The National Supervisory Authority for Welfare and Health (Valvira) is the competent authority receiving product notifications and on supervising compliances with provisions on ingredients, emissions and safety of products, packaging, and national marketing. The municipalities have the responsibility to supervise compliance with provisions on the sale, marketing and display bans in their own jurisdiction. They work under the guidance of Valvira and Regional State Administrative Agencies. ${ }^{1}$ Administrative courts review, on appeal, the legality of the decisions of an authority. The Supreme Administrative Court may, on appeal, review decisions of the regional administrative courts. The Market Court deals with cases concerning market law, competition law and other commercial juridical matters.

In 2014, on English language websites there were almost 8000 named flavours for e-cigarettes. ${ }^{15}$ There is increasing evidence that flavours attract youngsters to use e-cigarettes, ${ }^{16-22}$ making them nicotine dependent and exposing them to the other ingredients of e-cigarettes. The safety of flavours, in most cases, has been tested only for use as food additives but not when heated and vaped into the lungs. ${ }^{16}$ While little is known about the potential health hazards of flavours when vaped, the growing body of emerging knowledge raises serious concerns. ${ }^{23-28}$ Furthermore, labels on the liquids have been found to be inaccurate. ${ }^{29}$ The level of harm to health seems to depend on the properties of the liquid and the qualities of the device and its accessories. ${ }^{28} 3031$

There is a growing interest in regulating e-cigarettes and especially the use of flavours. ${ }^{8} 932$ Therefore, the Finnish experience on e-cigarettes and their regulation may be of wider interest.

\section{MATERIALS AND METHODS}

Data from Valvira on sales permits, notifications on e-cigarette products from manufacturers and importers, and Valvira municipal guidance on tobacco control and Valvira regulatory decisions concerning e-cigarettes were acquired. Documents produced for the legislative process, such as a government bill and notification to the EU and the responses to it, were analysed. Internet and Facebook pages of major e-cigarette business actors were studied. Clarifying discussions with tobacco control authorities were also held.
Table 1 Tobacco product and nicotine liquid retailers in Finland in December 2017 and December 2018

\begin{tabular}{lllllc}
\hline & \multicolumn{2}{l}{ December 2017 } & & \multicolumn{2}{l}{ December 2018 } \\
\cline { 2 - 3 } \cline { 5 - 6 } & $\begin{array}{l}\text { Number of } \\
\text { retailers }\end{array}$ & $\begin{array}{l}\text { \% of } \\
\text { retailers }\end{array}$ & & $\begin{array}{l}\text { Number of } \\
\text { retailers }\end{array}$ & $\begin{array}{l}\% \text { of } \\
\text { retailers }\end{array}$ \\
\hline $\begin{array}{l}\text { Tobacco product retail } \\
\text { licence only }\end{array}$ & 8400 & 98 & 6884 & 95 \\
$\begin{array}{l}\text { Nicotine liquid retail } \\
\text { licence* }\end{array}$ & 173 & 2 & 339 & 5 \\
All retailers & 8573 & 100 & 7223 & 100 \\
\hline * & & & & \\
\hline
\end{tabular}

*Includes those having retail licence for nicotine products only (143 in 2017 and 42 in 2018), as well as those having both licences (30 in 2017 and 297 in 2018).

In May 2019, public documents on appeals concerning e-cigarettes between 2017 and 2019 were requested from the Market Court and from all six administrative courts in continental Finland, using as keywords names of e-cigarette chains, shops and enterprises linked to e-cigarette businesses. Data were analysed descriptively.

\section{RESULTS}

\section{E-cigarettes on the Finnish markets}

In December 2017, only 2\% of all retailers for tobacco products or nicotine liquids had licences for selling nicotine liquids (table 1). Of the venues having retail licences for nicotine liquids, $83 \%$ had it only for nicotine liquids, indicating that e-cigarettes were sold almost exclusively by newly established e-cigarette shops. A year later, in December 2018, the number of retailers licenced for selling nicotine liquids had almost doubled, and 5\% of outlets selling tobacco products or nicotine liquids had a retail licence for the latter. The number of those having a retail licence only for selling nicotine liquids decreased from 143 to 42 (71\%), constituting $12 \%$ of retailers for nicotine liquids. Thus, while availability was still low, considerably more grocery stores and kiosks had acquired licences to sell nicotine liquids, in addition to other tobacco products, while the role of specialised e-cigarette shops had decreased.

Concerning the variety of products, by February 2019, Valvira had 8365 active product notifications concerning various e-cigarette-related devices, accessories and liquids, and 11003 additional inactive product notifications, meaning that 19368 notifications had been filed within less than 3 years. No information is available about the number of the notified products that have actually come on the market.

\section{Regulation of e-cigarettes and court cases Regulating marketing of e-cigarettes}

E-cigarette control is done under the auspices of tobacco control, and specific information on guidance on marketing e-cigarettes is scarce. In 2018, Valvira provided guidance or issued a decision 93 times on the marketing of tobacco or nicotine products, a $55 \%$ increase from 2016. The number also includes guidance given to other authorities. Valvira's resources amount mostly to dealing with questions and breaches reported to them.

In 2018, Valvira issued three decisions concerning breaches of the e-cigarette marketing ban. In one case, the marketing of e-cigarettes, nicotine liquids and nicotine-free liquids on the internet was discontinued when the company received a request for clarification from Valvira, but it continued on the company's Facebook site. The company claimed it did not have control over the contents of its Facebook site, which was hosted from another EU country. Valvira accepted this explanation. As 
of May 2019, this Facebook site-offering no information in the language of its host country and having site contact details in Finland-continued to actively promote Finnish e-cigarette shops and advertise its new website for purchasing flavours, which it created after Valvira's decision. The second Valvira decision concerned the advertising of a website selling e-cigarettes from Germany, but its activity was already discontinued before the decision.

A third decision, in November 2018, prohibited one of the major e-cigarette chains from marketing e-cigarettes on public transport, in newspapers and other marketing channels by referring to products regulated by the TA2016 that were marketed using advertising campaigns with expressions such as 'full service e-cigarette shop'. This e-cigarette enterprise appealed to the Market Court, constituting the only case concerning e-cigarettes at the Market Court.

\section{The ban on marketing by the Market Court}

The appeal argued that instead of advertising e-cigarettes, which was forbidden under TA2016, their marketing efforts concerned corporate image marketing, with the campaign advertising their business name and auxiliary business name, the auxiliary being the full service e-cigarette shop. Forbidding this type of marketing would, according to the appeal, violate their constitutional right to freedom of expression. It furthermore claimed that TA2016 lacked a clear definition for marketing and sales promotion, and therefore, to ensure legal certainty, the marketing ban should not be applied. According to the appeal, the public health reasons for banning tobacco marketing do not apply in this case.

The major dispute, therefore, concerned whether the advertising violated TA2016 section 68 on marketing, and whether a ban would infringe the principles of freedom of expression, create legal uncertainty or be disproportionate or unpredictable. In December 2018, the Court prohibited the implementation of Valvira's decision until it ruled. The main hearing was held in August 2019, and the ruling date will be given in September 2019. If either party is dissatisfied with the ruling, they can seek permission to appeal to the Supreme Court.

\section{Regulating flavours}

Municipal tobacco control authorities make about 2700 visits annually to retailers of tobacco and nicotine products. When it became evident that some municipal authorities were uncertain on the interpretation of TA2016 regarding selling flavours and were reluctant to ban their sale, Valvira provided municipalities with guidance. ${ }^{33}$ According to this guidance, some of the flavours actually meant for vaping were being sold ostensibly for other uses, and it was possible that a liquid could be subject to both regulations on foodstuffs and TA2016 as a product meant for vaping. In unclear cases, Valvira instructs municipalities to make an overall assessment to identify the intended use of the item. For example, flavours sold in a specialised e-cigarette shop were considered likely to be sold for vaping. If a shopkeeper insisted on selling the liquids for purposes other than vaping, its status as a shop specialising in tobacco and nicotine products could be reconsidered.

Having received this guidance from Valvira, municipalities issued decisions to e-cigarette shops demanding that they remove the flavours from their product range. Failure to comply with these decisions would result in a periodic fine. The decisions were usually preceded by two tobacco control visits and a hearing process.

\section{The ban on selling flavours for e-cigarettes by regional administrative courts}

Nine appeals on the municipalities' decisions demanding that e-cigarette shops remove flavours from sale were filed with four different regional administrative courts between May 2018 and April 2019 (table 2). Five appeals were made by one lawyer and three by another from another law firm; one appeal was signed by an e-cigarette shop owner, but the text was essentially identical to the appeals by lawyer 2 .

The number of appeals equates to $21 \%$ of all the retailers having a licence for selling only nicotine liquids as of December 2018. According to discussions with tobacco control authorities, due to ongoing court cases, some municipalities have refrained from intervening with the sale of flavours by additional retailers.

All nine appeals demanded that the municipalities' decisions be repealed. Eight requested that the implementation of the decision on removing e-cigarette flavours from sale be halted until the courts rule on the appeals, and in all those cases the courts so ordered.

The main dispute in all cases was whether or not the flavours sold by the e-cigarette shops corresponded to the description of products that were forbidden under TA2016, that is, whether the e-cigarette retailers were selling the flavoured liquids for vaping or for flavouring foods and drinks. All appeals maintained that the flavours sold by the e-cigarette shops were sold solely for flavouring food and drinks. They pointed out that selling of foodstuffs in specialised tobacco or e-cigarette shops was not prohibited by the law.

\begin{tabular}{|c|c|c|c|c|c|c|c|}
\hline $\begin{array}{l}\text { Court } \\
\text { case* }\end{array}$ & $\begin{array}{l}\text { Administrative } \\
\text { court }\end{array}$ & $\begin{array}{l}\text { Law } \\
\text { firm }\end{array}$ & $\begin{array}{l}\text { Sale of flavours detected } \\
\text { by tobacco control } \\
\text { (month/year) }\end{array}$ & $\begin{array}{l}\text { Municipal decision sent to } \\
\text { the entrepreneur } \\
\text { (month/year) }\end{array}$ & $\begin{array}{l}\text { Appeal to court on } \\
\text { decision } \\
\text { (month/year) }\end{array}$ & $\begin{array}{l}\text { Court order to suspend } \\
\text { enforcement } \\
\text { (month/year) }\end{array}$ & $\begin{array}{l}\text { Court decision or } \\
\text { the appeal } \\
\text { (month/year) }\end{array}$ \\
\hline 1 & 1 & 1 & October/2017 & April/2018 & May/2018 & May/2018 & \\
\hline 2 & II & 1 & November/2017 & June/2018 & June/2018 & June/2018 & May/2019 \\
\hline 3 & III & 1 & May/2017 & August/2018 & September/2018 & September/2018 & \\
\hline 4 & IV & 2 & July/2018 & October/2018 & October/2018 & November/2018 & \\
\hline 5 & 1 & 2 & March/2018 & December/2018 & January/2019 & February/2019 & \\
\hline 6 & 1 & 1 & March/2018 & January/2019 & January/2019 & March/2019 & \\
\hline 7 & III & $2 \dagger$ & August/2018 & March/2019 & March/2019 & March/2019 & \\
\hline 8 & IV & 2 & March/2018 & March/2019 & March/2019 & Not requested & \\
\hline 9 & IV & 1 & July/2018 & April/2019 & April/2019 & May/2019 & \\
\hline
\end{tabular}

* In chronological order by date of appeal submission.

tSigned by the entrepreneur, but contents essentially identical to those made by law firm 2 . 
The appeals argued that TA2016 was unclear and imprecise, and that it had been wrongly interpreted by the municipalities. They emphasised that only characterising flavours were forbidden. Lawyer 1 argued that TA2016 did not forbid the sale of liquids that could be vaped after being mixed with other liquids. Lawyer 2 argued that the law did not include flavours that could possibly be used for vaping, and that their flavours were imported or produced and labelled as foodstuffs. As evidence, cases 5, 7, 8 and 9 had a picture of a leaflet available in the shops presenting two generic recipes for the use of aromas in drinks and for baking.

The other arguments alleged discrimination against e-cigarette shops as compared with other shops selling nicotine liquids for vaping, as according to the claims, grocery stores could sell flavours, including concentrate juices, but specialised e-cigarette shops could not. While lawyer 1 based those arguments mainly on EU law, lawyer 2 based the same arguments mainly on the national administrative procedures act. Both argued that the treatment was not impartial and was disproportional for the objective sought. Lawyer 1 argued that because the same liquids could be also be sold in grocery stores, they could not be considered a product forbidden by TA2016. Arbitrary discrimination between different sales channels was claimed, based on a receipt from a grocery shop in Helsinki showing a purchase of nicotine liquids and various types of flavours in May 2018. A municipal tobacco control visit in November 2018 found no breaches in that store's practices. The visit by the author of this paper to the store and discussions with its staff in January 2019 verified proper practices adopted according to information received from tobacco control authorities instead of from the wholesaler.

Lawyer 2 also argued that the fact that flavours are also sold online was proof of such discrimination. While the online shops referred to were not specified in the appeals, two major websites advertising and selling flavours and e-cigarette accessories online are closely linked to the e-cigarette business, use names alluding to vaping (vapetalo.com and puffila.com) and are hosted outside of Finland but with contact information within Finland. These websites sell many of the same brands sold exclusively for vaping in other countries but with the added information that they are for foodstuffs. A third website for purchasing flavours is hosted in Finland and uses a name not linked to vaping, but to flavours more generally (makutiiviste.fi). The flavours are from a Finnish producer. This website is heavily advertised by an e-cigarette company Facebook site as theirs, despite claims to Valvira that they had no influence on it. The Facebook site is hosted outside Finland.

Five appeals by lawyer 1 citing preambular 47 on flavours and Article 24 of the TPD on free movement, and the EU Treaty TFEU Articles 34-36 argued that the perspectives of the EU law were not taken into account in the municipalities' decisions and that a preliminary ruling from the European Court of Justice (ECJ) should be requested in case the courts would not repeal the decisions to determine whether the municipalities' decisions were justified, necessary and proportionate, taking into account the high level of public health protection afforded by the TPD. The ECJ should also consider whether the decisions could lead to arbitrary discrimination or obstruction of free trade by states. Lawyer 2 cited the response by the European Commission (EC) to the Finnish notification, in which a clarification was requested on why flavours would be attractive to youth and why all flavours should be banned, with a recommendation to re-evaluate after a given time.

In May 2019, the first court ruling was made. It stated that the main purpose of specialised tobacco or nicotine product shops is to sell tobacco and nicotine products, and foodstuffs do not in principle belong to their selection of products, except on a limited scale. In the context of these specialised shops, it can be concluded that the flavours sold and displayed are meant for vaping. When these liquids are sold in grocery stores, they are part of a large selection of products, and tobacco and nicotine products are not displayed. The court rejected demands to ask the ECJ for a preliminary ruling. The ruling was the result of a vote (2-1). One of the judges reasoned that the flavours sold in the e-cigarette shop were not meant for vaping, as they were labelled as foodstuffs and were not marketed for vaping. The ruling is not final because an appeal has been made to the Supreme Administrative Court. The process at the Supreme Court can take $1-2$ years.

\section{DISCUSSION}

This study examined Finland's e-cigarette market and its challenges in enforcing stricter regulations on e-cigarettes than those required by the EU's TPD, with emphases on the role of specialised e-cigarette shops and their appeals to courts. Although the crucial role of specialised e-cigarette shops as retailers has diminished in the evolving Finnish e-cigarette market, other retail channels were not studied.

Product notifications rely on manufacturers and importers as regards the quality and safety of the e-cigarette products, including when these are heated and inhaled. According to Stratton $e t a l,{ }^{16}$ the safety of flavours, in most cases, has been only tested for use as food additives, not when heated and vaped into the lungs, and while the manufacturer or importer declares full responsibility for the quality and safety of the products, it remains unclear to what extent such information has been available in the notifications. The high number of submitted notifications with a multitude of different devices, liquids and flavours, the reported inaccuracies in labelling information, ${ }^{29}$ and the scarcity of safety data when heated and inhaled, ${ }^{16}$ including in various mixes of compounds, make scrutinising the quality of the notification information difficult. Ensuring the safety of flavoured e-cigarettes on the market has proven demanding even for the Food and Drug Administration. ${ }^{34}$ For small countries, this is unrealistic at the national level without a substantial increase of tobacco control resources.

Many of the flavours sold in Finland by the e-cigarette business are international brands for vaping. Other flavours were produced by a Finnish producer. As the importers and manufacturers of these flavours allegedly sell them as foodstuffs only, the risks may be shifted to the consumers, particularly if various liquids are mixed by consumers themselves. The use of internet and Facebook sites hosted outside Finland in countries with more lax regulation on e-cigarettes for their marketing further complicates enforcement of national regulation.

The length of the legal and preceding administrative processes serves to normalise the sale of flavours. While the first court ruling rejected the request to seek a preliminary ruling from the ECJ, appeals may ultimately be made to the ECJ using argumentation similar to that about, for example, smokeless tobacco (see, eg, C-151/1/).

In its reply to the Finnish notification on the stricter regulations on e-cigarettes, the EC recommended that Finland later review its regulations on flavours, based on new evidence. Mounting scientific evidence points towards keeping the ban both in terms of the role of flavours attracting youth and potentially harming their health ${ }^{16-28} 3536$ while calling into question the claims by the e-cigarette business that these measures to 
protect youth from flavours would not be justified, proportionate or necessary.

Based on the TPD's reporting requirements and following the recent recommendations of the $\mathrm{WHO},{ }^{37}$ the EU should consider its stands on e-cigarette regulation to protect young people, similarly to the USA, ${ }^{8}$ Canada ${ }^{9}$ and India. ${ }^{32}$ At the very least, a preapproval process for products to be vaped should be established at EU level, including flavours without nicotine. With the increasing number of products, new actors and new forms of marketing, resources for tobacco and nicotine product control need strengthening at national levels too.

Regulating new tobacco and nicotine products is increasingly challenging. New products are emerging with numerous variations and scant evidence on the potential health hazards that they may entail. It will be complicated to get epidemiological evidence of the safety and potential health hazards on the various products in this quickly evolving landscape of new nicotine and tobacco products. According to Drope $e t a l,{ }^{23}$ while e-cigarettes are still considered demonstrably less harmful than cigarettes, with the enormous heterogeneity of the products and minimal regulation, there is no guarantee that new products (and perhaps existing ones) are substantially less harmful than combustibles. We must step up efforts in terms of research, public information, regulation and its enforcement.

\section{What this paper adds}

- The regulation of e-cigarettes in Finland is stricter than that in other European Union (EU) countries, including a ban on characterising flavours in e-cigarette liquids and on marketing of e-cigarettes. Many countries are striving for strengthening their regulation on flavoured e-cigarette liquids, as concerns over their health effects have grown.

- Enforcing regulations is hampered by the enormous number and variety of e-cigarette products notified for potential market access, limited safety information available, the limited resources for tobacco control and the reluctance of the e-cigarette industry to comply with the regulations, resulting in multiple court cases.

- The EU should reconsider its stands on regulating flavours in e-cigarettes, the regulation of which was left to the member states, with their safety to be covered by a declaration by the manufacturers and importers.

\section{Twitter Eeva Ollila @EevaOllila}

Acknowledgements The author warmly thanks Isabella Lencione, senior officer at Valvira, for her expert advice during this research; Risto Fonselius and Pekka Salminen of Kuuskulman tapaustoimisto for assistance on acquiring documentation; and Mark Waller for language checking. The two anonymous reviewers, whose comments substantially improved the article, are sincerely thanked. Nevertheless, the responsibility for the content of this article lies solely with the author

Contributors The author has designed the study, has done the analyses and has written the article by herself.

Funding Cancer Society of Finland.

Competing interests None declared.

Patient consent for publication Not required.

Provenance and peer review Not commissioned; externally peer reviewed.

Open access This is an open access article distributed in accordance with the Creative Commons Attribution Non Commercial (CC BY-NC 4.0) license, which permits others to distribute, remix, adapt, build upon this work non-commercially, and license their derivative works on different terms, provided the original work is properly cited, appropriate credit is given, any changes made indicated, and the use is non-commercial. See: http://creativecommons.org/licenses/by-nc/4.0/.

\section{ORCID iD}

Eeva Ollila http://orcid.org/0000-0003-4791-3088

\section{REFERENCES}

1 Tobacco Act 549/2016 (Tupakkalaki 29.6.2016/549) [Internet]. Helsinki: Ministry of Social Affairs and Health [cited 2018 Feb 8]. English translation. Available: https:// www.finlex.fi/en/laki/kaannokset/2016/en20160549

2 Directive 2014/40/EU of the European Parliament and of the Council of 3 April 2014 on the approximation of the laws, regulations and administrative provisions of the Member States concerning the manufacture, presentation and sale of tobacco and related products and repealing Directive 2001/37/EC (Text with EEA relevance), Official Journal of the European Union, 29.4.2014. Available: https://ec.europa.eu/ health/sites/health/files/tobacco/docs/dir_201440_en.pdf

3 Ruokolainen O, Ollila H, Patrick S. Heloma A: Kiistanalainen sähkösavuke - käytön yleisyys, muutokset ja taustatekijät. [Controversial e-cigarette - prevalence of use, trends and background factors] Yhteiskuntapolitiikka 81 2016:1:17-30.

4 Ollila E, Fonselius R, Salminen P. Sähkösavukkeiden saatavuus ja valvonta uuden tupakkalain aikana. [Accessibility and control of e-cigarettes under the new Tobacco Act] Yhteiskuntapolitiikka 2019: 84:70-79, first published in electronic form in May 15, 2018. Available: http://urn.fi/URN:NBN:fi-fe2018051424038

5 Kennedy RD, Awopegba A, De León E, et al. Global approaches to regulating electronic cigarettes. Tob Control 2017;26:440-5.

6 Hallituksen esitys eduskunnalle tupakkalaiksi ja eräiksi siihen liittyviksi laeiksi, HE 15/2016 vp [Government Bill to the Parliament regarding the Tobacco Act and certain related acts 15/2016]. Available: https://www.eduskunta.fi/FI/vaski/KasittelytiedotV altiopaivaasia/Sivut/HE_15+2016.aspx

7 Laverty AA, Filippidis FT, Vardavas Cl. Patterns, trends and determinants of e-cigarette use in 28 European Union member states 2014-2017. Prev Med 2018:116:13-18.

8 FDA. Statement: Statement from FDA Commissioner Scott Gottlieb, M.D., on proposed new steps to protect youth by preventing access to flavored tobacco products and banning menthol in cigarettes. [cited 2019 Feb 7]. Available: https://www.fda.gov/ NewsEvents/Newsroom/PressAnnouncements/ucm625884.htm

9 Reducing youth access and appeal of vaping products, consultation on potential regulatory measures. Health Canada, April 2019. Available: https://www.canada. ca/en/health-canada/programs/consultation-reducing-youth-access-appeal-vapingproducts-potential-regulatory-measures.html

10 National Institute for Health and Welfare (THL). School Health Promotion Study. Indicators available from the Sotkanet Indicator Bank. Available: https://sotkanet.fi/ sotkanet/en/index

11 Ollila H, Ruokolainen O, Kinnunen J, et al. Nuorten nikotiinituotteiden käyttö [Use, determinants and health risks of alternative nicotine products among youth]. Duodecim 2017;133:2045-53

12 Ruokolainen $\mathrm{O}$, Ollila $\mathrm{H}$, Karjalainen $\mathrm{K}$. Determinants of electronic cigarette use among Finnish adults: results from a population-based survey. Nord Stud Alcohol Dr 2017:34:471-80.

13 Kinnunen JM, Ollila H, El-Amin SE-T, et al. Awareness and determinants of electronic cigarette use among Finnish adolescents in 2013: a population-based study. Tob Control 2015;24:e264-70

14 European Commission. Notification 2015/490/FIN: Notification by the Finnish Government to the EU. Government bill to Parliament regarding an amendment to the Tobacco Act and certain related acts. European Commission; 2015 Aug [cited 2019 Feb 11]. Available: http://ec.europa.eu/growth/tools-databases/tris/en/index.cfm/ search/?trisaction=search. detail\&year $=2015 \&$ num $=490 \& \mathrm{mLang}=E N$

15 Zhu S-H, Sun JY, Bonnevie E, et al. Four hundred and sixty brands of e-cigarettes and counting: implications for product regulation. Tob Control 2014;23:iii3-9.

16 Stratton K, Kwan LY, Eaton DL. Public health consequences of e-cigarettes. A consensus study report of the National academies of sciences, engineering and medicine. USA: The National Academic Press, 2018

17 Pepper JK, Ribisl KM, Brewer NT. Adolescents' interest in trying flavoured e-cigarettes. Tob Control 2016:25:ii62-6.

18 Ambrose BK, Day HR, Rostron B, et al. Flavored tobacco product use among US youth aged 12-17 years, 2013-2014. JAMA 2015:314:1871-3.

19 Harrell MB, Loukas A, Jackson CD, et al. Flavored tobacco product use among youth and young adults: What if flavors didn't exist? Tob Regul Sci 2017;3:168-73.

20 Morean ME, Butler ER, Bold KW, et al. Preferring more e-cigarette flavors is associated with e-cigarette use frequency among adolescents but not adults. PLOS One 2018:13:e0189015.

21 Nordic Welfare Centre. The significance of flavour additives in the use of moist snuff and e-cigarettes - with a focus on young people and the Nordic region [Internet]. Stockholm: Nordic Welfare Center; 2019 Jan [cited 2019 Feb 11]. Available: https:// nordicwelfare.org/wp-content/uploads/2019/01/The-significance-of-flavour-additivesin-the-use-of-moist-snuff-and-e-cigarettes.pdf 
22 Krishnan-Sarin S, Green BG, Kong G, et al. Studying the interactive effects of menthol and nicotine among youth: an examination using e-cigarettes. Drug Alcohol Depend 2017;180:193-9.

23 Drope J, Cahn Z, Kennedy R, et al. Key issues surrounding the health impacts of electronic nicotine delivery systems (ENDS) and other sources of nicotine. CA Cancer Clin 2017:67:449-71.

24 Erythropel HC, Jabba SV, DeWinter TM, et al. Formation of flavorant-propylene glycol adducts with novel toxicological properties in chemically unstable e-cigarette liquids. Nicotine Tob Res 2018;nty192.

25 Muthumalage T, Prinz M, Ansah KO, et al. Inflammatory and oxidative responses induced by exposure to commonly used e-cigarette flavoring chemicals and flavored e-liquids without nicotine. Front Physiol 2017;8:1130.

26 Leigh NJ, Lawton RI, Hershberger PA, et al. Flavourings significantly affect inhalation toxicity of aerosol generated from electronic nicotine delivery systems (ends). Tob Control 2016;25:ii81-7.

27 Lee WH, Ong S-G, Zhou Y, et al. Modeling cardiovascular risks of e-cigarettes with human-induced pluripotent stem cell-derived endothelial cells. J Am Coll Cardiol 2019;73:2722-37

28 Lerner CA, Sundar IK, Yao H, et al. Vapors produced by electronic cigarettes and e-juices with flavorings induce toxicity, oxidative stress, and inflammatory response in lung epithelial cells and in mouse lung. PLoS One 2015;10:e0166732.

29 Hahn J, Monakhova YB, Hengen J, et al. Electronic cigarettes: overview of chemical composition and exposure estimation. Tob Induc Dis 2014;12:23.
30 Kosmider L, Sobczak A, Fik M, et al. Carbonyl compounds in electronic cigarette vapors: effects of nicotine solvent and battery output voltage. Nicotine Tob Res 2014;16:1319-26.

31 Jensen RP, Luo W, Pankow JF, et al. Hidden formaldehyde in e-cigarette aerosols. N Engl J Med 2015;372:392-4.

32 Mahase E. E-cigarettes: Indian government research council recommends "complete prohibition". BMJ 2019;365.

33 Valvira [Finnish National Supervisory Authority for Welfare and Health]. Tupakkalain soveltaminen nesteisiin, joissa on tunnusomainen tuoksu tai maku. [The application of the Tobacco Act to liquids containing a characteristic odor or taste] Helsinki, 2018. Available: https://www.valvira.fi/-/tupakkalain-soveltaminen-nesteisiin-joissa-ontunnusomainen-tuoksu-tai-maku [Accessed 11 Feb 2019].

34 FDA. Lung illnesses associated with use of Vaping products. information for the public, FDA actions, and recommendations. Available: https://www.fda.gov/news-events/ public-health-focus/lung-illnesses-associated-use-vaping-products [Accessed 11 Sep 2019].

35 Christiani DC. Vaping-Induced lung injury. N Eng/ J Med 2019. doi:10.1056/ NEJMe1912032. [Epub ahead of print: 06 Sep 2019].

36 Kennedy CD, van Schalkwyk MCl, McKee M, et al. The cardiovascular effects of electronic cigarettes: a systematic review of experimental studies. Prev Med 2019;127:105770.

37 WHO. WHO Report on the global tobacco epidemic, 2019. Geneva: World Health Organization, 2019. 